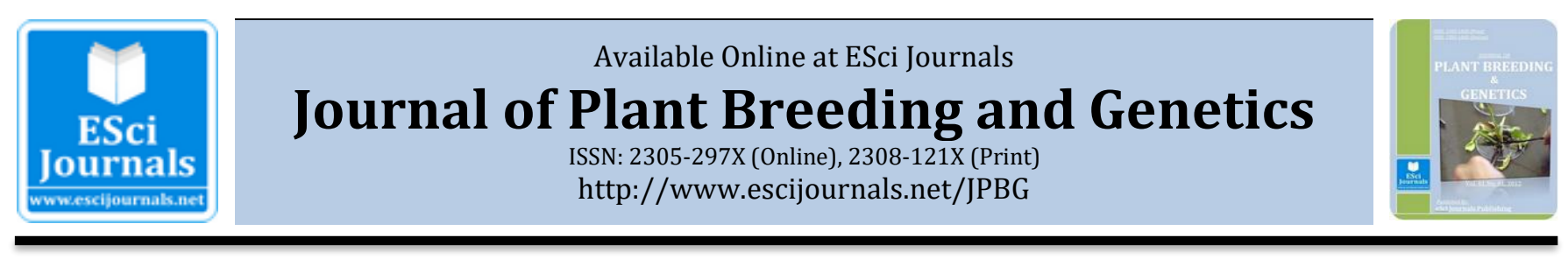

\title{
EVALUATION OF GENETIC DIVERSITY IN BARLEY (HORDEUM VULGARE) GENOTYPES USING PROTEIN PROFILING
}

\author{
Manal Eid* \\ Botany Department, Faculty of Agriculture, Suez Canal University, 41522, Ismailia, Egypt.
}

\section{A B S T R A C T}

The knowledge of the genetic diversity of barley (Hordeum vulgare) genotypes based on protein polymorphism is very important for breeding programs. The purpose of the current study was to determine the genetic diversity and relationships among ten barley genotypes by using Sodium dodecyl sulphate polyacrylamide gel electrophoresis (SDSPAGE) for protein profiles. A total number of 30 bands with molecular weights ranging from 12 to 148 KD were detected. Out of these, five bands were observed monomorphic. Rest of the bands had shown polymorphism to the extent of $83.3 \%$ among the test genotypes. The genetic similarity of the ten genotypes tested varied from 0.26 to 1.00 with an average of 0.51 . Cluster analysis divided the ten genotypes into two major clusters comprising four subclusters, which was consistent with the systematic classification of barley done in previous studies. The results of this study indicated that the genotypes of barley could effectively be differentiated based on polymorphism, detected between protein patterns. SDS-PAGE presented a higher differentiation power and better repeatability; thus, could be used as a rapid and reliable method for genetic diversity analysis and laid a solid foundation for future barley breeding.

Keywords: Barley, SDS-PAGE, genetic diversity, polymorphism, cluster analysis.

\section{INTRODUCTION}

Barley (Hordeum vulgare) is one of the first plants domesticated by humans and thus, genetic variation occurred in its genome and it has been causing genetic diversity in its wild ancestors (Ghaderi et al., 2003). Cultivated barley is an annual diploid species, having a basic chromosome number of $7(2 \mathrm{n}=2 \mathrm{x}=14)$. Barley has many diploid, tetraploid, and hexaploid wild relatives. Barley is the only species (of approximately 28 Hordeum species) that is cultivated on a large scale. Barley is one of the most important crops grown throughout the world, ranking fourth among the world's cultivated cereal crops after wheat, rice, and maize (Feng et al., 2006). Barley has a wide range of adaptability and cultivates in areas where other crops don't grow well due to the low rainfall, salinity, heat, and cold conditions (Mer et al., 2000; Saisho and Takeda, 2011). This crop used as a fodder for animals, malt preparation and other human consumptions (Masoudi et al., 2008). Farmer

* Corresponding Author:

Email: eid_manl@hotmail.com

(C) 2018 ESci Journals Publishing. All rights reserved. preferences and breeder selection criteria lead to the narrowing of germplasm base (Chen et al., 2012). Only a few elite germplasm accessions are often tending to be used as parents for the next cycle of breeding leading to greater genetic uniformity and germplasm disappearance. To assure the safety of crop production, it is necessary to widen genetic background in crop breeding. It is well known that genetic diversity is the basis of biological diversity, and thus, it plays a key role in making progress in crop breeding in future (Jisha et al., 2015; Pournosrat et al., 2018). Evaluation of genetic diversity using molecular markers is a cornerstone for understanding genome structure, the characterization and maintenance of genetic variation on plant germplasm, identifying genes underlying important traits and devising optimal breeding strategies for crop improvement (Kut'kaHlozákovás et al., 2016). Further scope of crop improvement depends on the conserved use of genetic variability and diversity in plant breeding programmes and use of new biotechnological tools. Since genetic diversity provides information to monitor germplasm and prediction of potential genetic gains. 
Genetic similarity/distance estimates among genotypes are helpful in the selection of parents to be used in a breeding programme. The study of genetic diversity is also important for varietal identification, proper purity maintenance, for the implementation of plant variety protection rights (Ahmed et al., 2010).

The introduction of biochemical and molecular techniques has allowed a more accurate valuation of genetic relationships of barely cultivars: total protein profiles (Dakir et al., 2002), restriction fragment length polymorphism (RFLP) and random amplified polymorphic DNA (RAPD) (Al-Hadeithi et al., 2012), simple sequence repeat (SSRs) (Chen et al., 2012), amplified fragment length polymorphism (AFLP) (Zhang and Ding, 2007). As these molecular markers are not influenced by the environment, are abundant and do not require previous pedigree information (Bohn et al., 1999). The advantages and limitations of molecular techniques have been extensively discussed (Karp, 1995). But the suitability of a marker system should not only base in its ability to discriminate between individuals and the number of loci which can be assayed simultaneously, but also by the total cost (research time and consumables) of the technique. Therefore, the cost of techniques could be the limiting factor in many developing countries which may be poor in terms of economics, but rich in genetic resources. Consequently, relatively cheap techniques that demand less sophisticated laboratory equipment could be the appropriate choice (Aman, 1995; Baloch et al., 2014) to make reasonable scientific advancements. However, protein markers are useful tools to identify cultivar and classification of crop species to study genetic diversity, thereby improving the efficiency of plant breeding programs (Gianibelli et al., 2001; Kut'ka-Hlozákovás et al., 2016; Pérez de, 1993; Sharma and Krishna, 2017). Among biochemical techniques, Sodium dodecyl sulfate-polyacrylamide gel electrophoresis (SDS-PAGE) due to its simplicity, minimum cost in time and labor, and effectiveness is commonly used in the studies of plants genetic diversity (Abou-Ellail et al., 2014; Ahmed et al., 2010; Masoumi et al., 2012; Radwan et al., 2013; Sadia et al., 2009).

Since this technique is non-destructive and needs only a small amount of tissue to obtain sufficient material for analysis and the rest of the seed could be grown into mature plants and seed can be obtained from the tested seeds. In addition, electrophoresis of protein can be analyzed without previous knowledge of their genetic control, as dominant markers (presence-absence) when considering each band as a different genetic locus (Dakir et al., 2002). It is a direct multi-locus approach involving the electrophoretic examination of protein which is encoded genetically at more than one locus and which display a substantial degree of molecular polymorphism. Nowadays, this method is considered as a low cost, high reproducible and rapid approach, because of that it became accepted valuable tool, although it has been neglected.

Objectives of the present study were: 1 . Patterns for the identification and characterization of the phylogenetic relationships among ten genotypes of barely identified by SDS - PAGE, 2. to establish a baseline to assist future conservation and breeding programmes of this species. 3. to prove the efficiency of this method in estimating the genetic diversity.

\section{MATERIALS AND METHODS}

Plant Material: Ten barley genotypes differencing in tolerance to abiotic stress and biotic stress were kindly provided by Field Crops Research Institute, Agricultural Research Center, Egypt and were used as plant material in this study. Pedigree and description of these genotypes are presented in Table 1.

SDS-PAGE Analysis: The SDS-PAGE is a well recognized tool for distinguishing cultivars of a crop species (Gardiner and Forde, 1992). The present study was therefore undertaken to distinguish among the ten given genotypes of barley using SDS-PAGE.

Protein sample extraction: Electrophoresis was done on 15 to 20-day old greenhouse-grown seedlings. Ten plants were sampled for each genotype. Of leaf, $0.5 \mathrm{~g}$ was taken and ground in a cold pestle mortar with liquid nitrogen and mixed with $2 \mathrm{~mL}$ extraction buffer containing $1 \mathrm{M}$ Tris $\mathrm{HCl}, \mathrm{pH}$ 8.0, $250 \mathrm{mM} \mathrm{NaCl}, 0.25$ mM EDTA. Samples were transferred to Eppendorf tubes and left in the refrigerator overnight, then vortexed for $15 \mathrm{~s}$ and centrifuged at $13,000 \mathrm{rpm}$ at $4^{\circ} \mathrm{C}$ for $10 \mathrm{~min}$. The pellets were collected and the steps above were repeated twice. After that $1 \mathrm{~mL}$, non-water soluble protein buffer (SDS $10 \mathrm{mM} \mathrm{b}$ mercaptoethanol, $1 \mathrm{M}$ Tris $\mathrm{HCl}, 0.25 \mathrm{mM}$ EDTA) was added to each pellet and mixed well and left in the refrigerator overnight. The sample was then vortexed and centrifuged at $13,000 \mathrm{rpm}$ for $10 \mathrm{~min}$ under cooling. The supernatant, considered as the non-water soluble protein extract, was transferred to a new Eppendorf tube. Protein concentration was determined by absorbance at $595 \mathrm{~nm}$ using a spectrophotometer and expressed as $\mu \mathrm{g} g-1$ fresh weight (Bradford, 1976). A standard curve for protein was prepared with bovine serum albumin. 
Table 1. Pedigree and Description of ten barley genotypes.

\begin{tabular}{|c|c|c|c|}
\hline Number & Genotype & Pedigree & Description \\
\hline 1 & Arar & Perga/Sekitorisai & Moderate tolerant to salinity \\
\hline 2 & Giza123 & Giza 117 /FA086 & $\begin{array}{l}\text { Six rows, Egyptian barley variety, } \\
\text { precocious, moderately productive in the } \\
\text { favourable conditions and tolerant to } \\
\text { salinity and fungi diseases. }\end{array}$ \\
\hline 3 & Beecher & Introduced to Egypt and named Giza 118 & Sensitive tolerant to salinity \\
\hline 4 & Giza 124 & Giza 117/Bahteem52/Giza118/FA086 & $\begin{array}{l}\text { Six rows, Egyptian barley variety moderately } \\
\text { productive in the favourable conditions and } \\
\text { tolerant to salinity and fungi diseases. }\end{array}$ \\
\hline 5 & Mari & Bouns X Ray-mutant & Moderate tolerant to salinity \\
\hline 6 & Rihane-03 & $\begin{array}{l}\text { AS 46//AVT } 11 \text { ATHS 2L-1AP-3AP-OAP } \\
\text { realized at ICARDA }\end{array}$ & $\begin{array}{l}\text { Six rows, Algerian barley improved variety, } \\
\text { moderately tolerant to drought and salinity }\end{array}$ \\
\hline 7 & Line1 & $\begin{array}{l}\text { ICB890775-7AP-0AP-0AP-10AP-0AP- } \\
\text { 1AP-0AP }\end{array}$ & Sensitive to salinity \\
\hline 8 & Line2 & CB95-0281-0AP-6AP-0AP-7TR-1TR-0AP & Tolerant to salinity \\
\hline 9 & Line3 & ICB-1390-0412AP-0AP & Sensitive to salinity \\
\hline 10 & Line4 & ICB-91-0476-0AP-0AP & Sensitive to salinity \\
\hline
\end{tabular}

Separation of protein samples: A volume of $50 \mu \mathrm{L}$ of non-water soluble protein fraction was added to $10 \mu \mathrm{L}$ of 2-Mercaptoethanol and boiled in a water bath for 10 min, then $10 \mu \mathrm{L}$ Bromophenol blue was added to each tube before sample loading. A volume of 15- $20 \mu \mathrm{L}$, depending on the concentration of protein in the sample were applied to each well by micropipette and control wells were loaded according to the methods described previously (Laemmli, 1970). Low-molecular-weight standard proteins from Sigma Chemical Co. (St. Louis, MO) were prepared according to the manufacturer's instructions and run on one lane of each gel. Gels were shaken gently until the background of the gel became clear and polypeptide bands were clearly visible.

Data Analysis: To evaluate the similarity of the patterns, the matrix of identity indexes (ii) was constructed for all pairs of genotypes. Identity index (in \%) for each genotype pair was calculated as the proportion of common bands number to all bands number multiplied by 100 . Analysis of electrophoretic data (0 and 1 ) obtained from SDS-PAGE was performed using NTSYS-pc (numerical taxonomy and multivariate analysis system) (Rohlf, 1987). Cluster diagram was constructed based on an unweighted pair-group method with arithmetic average (UPGMA).

\section{RESULTS AND DISCUSSION}

The SDS-PAGE analysis led to the detection of a total number of 30 bands with molecular weights ranging from 12 to $148 \mathrm{KD}$ (Table 2). These results partially agree with earlier findings of Shekhghasemi et al. (2013) who examined 21 bands from 23 genotypes of barley and their molecular weight was within the range of 21.72 to $82.04 \mathrm{KD}$. In addition, five polypeptide bands at molecular weight positions 63.0, 47.0, 39.0, 36.0, and 12.0 KD were found to be monomorphic. Tripathy et al. (2016) reported that the genes controlling the expression of the monomorphic bands appeared to behave in single blocks. Rest of the 25 bands had shown polymorphism to the extent of $83.3 \%$ among the test genotypes. Although the barley is highly inbred, with low heterozygosity, the high value of polymorphism found in this investigation. It might be an inherent consequence of the selection process and it was possible the homozygosity of protein loci were reached in the following generations, and the genotypes were a mixture of homozygotes for different alleles in many loci (Maris, 1992). However, the data in Table 2 showed variation in the location of the protein bands based on their molecular weight. There are four regions which might be supported by the existence of four different encoding to determine the synthesis of proteins in barley. The first region had the highest molecular weight (more than 63 $\mathrm{kD}$ ) was the most polymorphic, whereas, the other three regions were varied between $12 \mathrm{kD}$ and $63 \mathrm{kD}$, had the 
least polymorphic, in addition to monomorphic. These polymorphisms may result from differences in the DNA sequences that code for the peptides or from differences in the genes involved in post-transcriptional Changes (Mzid et al., 2016; Vargas et al., 2001).

Nevertheless, a wide range of intra-specific variation in protein profiles was observed in the present study. The resulting data matrix of the presence and absence of bands resolved 97 polymorphic polypeptide bands out of total 147 bands over all the ten test genotypes which reveal 66\% polymorphism (Table 2). Moreover, a number of polypeptide bands in each genotype ranged from eight (Line 1) to as high as 21 bands (Mari) with an average of 14.7 bands. While Arar and Giza124 recorded 20 polypeptide bands each. Table 3 showed that maximum polymorphism (85\%) was observed in Arar genotype while minimum polymorphism $(37 \%)$ was in Line1. The high diversity observed in Arar genotype proteins may be due to being the result of gene silencing in these proteins (Lawrence and Shepherd, 1980).

Table 2. Electrophoretic (SDS-PAGE) polypeptide banding pattern of the protein in ten barley genotypes.

\begin{tabular}{|c|c|c|c|c|c|c|c|c|c|c|c|c|c|}
\hline \multirow{2}{*}{$\begin{array}{c}\text { Band } \\
\text { No. }\end{array}$} & \multirow{2}{*}{$\mathrm{Rf}$} & \multirow{2}{*}{ MW } & Arar & Giza 123 & Beecher & Giza 124 & Mari & Rihane & line1 & Line2 & Line3 & Line4 & \multirow{2}{*}{ Total } \\
\hline & & & 1 & 2 & 3 & 4 & 5 & 6 & 7 & 8 & 9 & 10 & \\
\hline 1 & 0.08 & 148 & - & - & - & - & - & + & + & + & + & + & 5 \\
\hline 2 & 0.016 & 124 & + & + & - & + & + & - & - & - & - & - & 4 \\
\hline 3 & 0.05 & 121 & + & + & + & + & - & - & - & - & - & - & 4 \\
\hline 4 & 0.08 & 120 & - & - & - & + & + & - & - & - & - & - & 2 \\
\hline 5 & 0.133 & 108 & + & + & + & + & + & - & - & - & - & - & 6 \\
\hline 6 & 0.15 & 106 & + & + & + & + & + & - & - & - & - & - & 5 \\
\hline 7 & 0.23 & 96 & - & - & - & + & - & - & - & - & - & - & 1 \\
\hline 8 & 0.26 & 94 & + & + & + & + & + & + & + & - & + & + & 9 \\
\hline 9 & 0.28 & 87 & - & - & - & - & + & - & - & - & - & - & 1 \\
\hline 10 & 0.35 & 67 & - & - & - & - & + & - & - & - & - & - & 1 \\
\hline 11 & 0.36 & 63 & + & + & + & + & + & + & + & + & + & + & 10 \\
\hline 12 & 0.38 & 59 & + & - & - & + & + & - & - & - & - & - & 3 \\
\hline 13 & 0.433 & 47 & + & + & + & + & + & + & + & + & + & + & 10 \\
\hline 14 & 0.45 & 45 & + & - & + & - & - & - & - & - & - & - & 2 \\
\hline 15 & 0.5 & 42 & - & + & - & - & - & - & - & - & - & - & 1 \\
\hline 16 & 0.51 & 39 & + & + & + & + & + & + & + & + & + & + & 10 \\
\hline 17 & 0.53 & 36 & + & + & + & + & + & + & + & + & + & + & 10 \\
\hline 18 & 0.55 & 33 & - & + & + & + & + & - & - & - & - & - & 4 \\
\hline 19 & 0.58 & 30 & - & + & - & + & - & - & - & - & - & - & 2 \\
\hline 20 & 0.6 & 28 & + & + & + & - & - & + & - & + & + & + & 7 \\
\hline 21 & 0.633 & 26 & - & - & - & + & + & - & - & - & - & - & 2 \\
\hline 22 & 0.65 & 24 & + & - & + & + & + & - & - & - & - & - & 4 \\
\hline 23 & 0.66 & 23 & - & - & - & - & - & + & + & + & + & + & 5 \\
\hline 24 & 0.7 & 22 & + & - & + & + & + & - & - & - & - & - & 4 \\
\hline 25 & 0.76 & 21 & + & - & + & - & - & - & - & - & - & - & 2 \\
\hline 26 & 0.816 & 19 & + & + & + & - & + & - & - & - & - & - & 4 \\
\hline 27 & 0.83 & 18 & + & + & + & + & + & + & - & + & + & + & 9 \\
\hline 28 & 0.85 & 17 & + & - & + & + & + & + & - & + & + & - & 7 \\
\hline 29 & 0.86 & 14 & + & + & + & - & + & & - & & & - & 4 \\
\hline 30 & 0.9 & 12 & + & + & + & + & + & + & + & + & + & + & 10 \\
\hline Total & and & & 20 & 17 & 19 & 20 & 21 & 11 & 8 & 10 & 11 & 10 & 147 \\
\hline
\end{tabular}


Table 3. Numbers of protein bands and polymorphism percentage in ten barley genotypes.

\begin{tabular}{lccc}
\hline Genotype & $\begin{array}{c}\text { Number } \\
\text { of bands }\end{array}$ & $\begin{array}{c}\text { Polymorphic } \\
\text { bands }\end{array}$ & $\begin{array}{c}\text { Polymorphism } \\
\text { percentage } \%\end{array}$ \\
\hline Arar & 20 & 17 & 85 \\
Giza 123 & 17 & 12 & 71 \\
Beecher & 19 & 14 & 75 \\
Giza 124 & 20 & 15 & 75 \\
Mari & 21 & 16 & 76 \\
Rihane & 11 & 6 & 54 \\
Line1 & 8 & 3 & 37 \\
Line2 & 10 & 5 & 50 \\
Line3 & 11 & 6 & 54 \\
Line 4 & 10 & 5 & 50 \\
\hline
\end{tabular}

The polymorphic nature of a cultivar is important for identification. Trustworthy samples of cultivars are necessary to ensure representative cultivars and not an inadvertent mixture(Echart-Almeida and Cavalli-Molina, 2000). Since pure seeds maintained by donors were used in this investigation, the polymorphic protein patterns were considered representative of the ten test genotypes.

Therefore, proteins being the direct gene products reflect the genomic composition of lines accurately to some extent and, are ideal for the study of genotypic distinctiveness. Out of 30 polypeptide band profiles, only one protein type (monomorphic) was common in all genotypes and the other 29 protein types/profiles (polymorphic) were detected for protein expression in the present ten of test genotypes. Therefore, proteins can be regarded as markers of structural genes that code them. The proximity of the processes between protein synthesis and primary genetic information (DNA) also largely reduces or even eliminates any environmental interaction in protein composition. Thus, analyses of protein composition have in fact become analyses of gene expression, while methods for protein composition comparison enable the measuring of genetic variability among individuals and populations (Cooke, 1994).

The frequency of genotypes revealing each band was shown to be as minimum as 1 to maximum 10 indicating a wide range of protein expression among the test genotypes (Table 2). Eight test genotypes revealed their characteristic genotype-specific polypeptide banding pattern while both Rihane-3 and Line3 revealed common protein types. Such a high degree of homology in polypeptide banding pattern among some of the genotypes might be due to similar ancestry with the narrow genetic base. This could also be due to duplications in collections(Maris, 1992). It is suggested that the genotypes with similar banding patterns should be studied in detail for agronomic and biochemical traits, including 2-D electrophoresis and DNA markers, for better management of the gene bank (Karuppanapandian et al., 2006).

Genetic variation in a set of germplasm has an important role in the identification of varieties. Polymorphism in electrophoretic banding pattern of proteins is associated with the genotype's genetic background and thus it can be used to understand the genetic makeup (Shuaib et al., 2007). Giza124 and Mari revealed a unique band $120 \mathrm{kD}$ which is absent in all other test genotypes. Similarly, 96 $\mathrm{kD}$ band was unique to Giza124. Similarly, $87 \mathrm{kD}$ band and $67 \mathrm{kD}$ band were unique to Mari. Out of ten genotypes, only Giza 123 revealed a unique band $42 \mathrm{kD}$. In contrast, an $18 \mathrm{kD}$ was shown to be present in all genotypes except in Line1. However, an average of alternatives per band (presence or absence) in each genotype as a variability parameter, which would be equivalent to the number of alleles per locus if the alternatives presence or absence were controlled by dominant and recessive alleles, respectively (Heisel et al., 1986; Sadia et al., 2009). Such genotype -specific protein markers could be reliably and useful in the studies of genetic diversity and classification of adapted cultivars and in breeding programs through markerassisted selection (MAS).

Genetic similarity based on Jaccard's coefficient ranged from 0.26 to 1.00 with an average of 0.51 (Table 4). The values of identity indexes were arranged into four groups $0-25 \%$; $26-50 \%$; $51-75 \% ; 76-100 \%$ and the number of genotype pairs belongs to each group was represented graphically (Figure 1). Forty-five values of identity indexes were found out the only 20 possible paired genotypic combinations have similarity coefficient value more than 0.51 including twelve pairs in group 51-75\% identity indexes and other eight pairs in group 76-100\%, indicating fair degree of homology among the test materials but no pair had identity indexes lesser than $25 \%$ (Table 4 and Figure 1). This may be because plant breeders tend to have narrow genetic diversity among the parents they use in their crossing programmes (Redden et al., 2007) and suggest the similarity of genes responsible for seed storage proteins (Ali et al., 2007). Among the ten genotypes, Rihane-3 with Line3 showed 
the highest similarity index (100). It might due to uniformity in the major bands between the two genotypes and it could be these proteins are conserved by gene coding (Javaid et al., 2004). However, Maris (1992) analyzed the genetic similarity among different barley cultivars and noted a great similarity among them. He concluded that the similarity could reflect the common origin of many of these cultivars. This result indicates the power of selection to lessen the genetic diversity of proteins, especially for a trait that is controlled by a few major genes (Baenziger et al., 2001). While the lowest similarity index was found between Mari with line1 (0.26) followed by Giza124 with Line1
(0.27) and Beecher with Line1 (0.28). Since the ten barley genotypes have the different pedigree, the reason to find the levels of diversity in some genotypes could be to their protein are controlled by multigene families that have arisen by duplication and divergence from an ancestral gene through nucleotide substitutions, insertions, and deletions. These last two mutation types have produced a variable number of repetitive sequences inside the corresponding genes (Shewry, 1995). The result reflected the diversity could be indicated to the expected heterozygosity under random mating conditions. Such genotypic combinations could be selected in hybridization programme.

Table 4. Jaccard similarity coefficients of ten barley genotype's protein bands.

\begin{tabular}{lcccccccccc}
\hline Genotssype & Arar & Giza123 & Beecher & Giza124 & Mari & Rihane & Line1 & Line2 & Line3 & Line4 \\
\hline Arar & 1.00 & & & & & & & & & \\
Giza123 & 0.61 & 1.00 & & & & & & & & \\
Beecher & 0.86 & 0.64 & 1.00 & & & & & & & \\
Giza124 & 0.60 & 0.54 & 0.56 & 1.000 & & & & & & \\
Mari & 0.64 & 0.52 & 0.60 & 0.71 & 1.00 & & & & & \\
Rihane & 0.41 & 0.40 & 0.43 & 0.39 & 0.33 & 1.00 & & & & \\
Line1 & 0.27 & 0.32 & 0.29 & 0.27 & $\mathbf{0 . 2 6}$ & 0.73 & 1.00 & & & \\
Line2 & 0.36 & 0.35 & 0.38 & 0.30 & 0.29 & 0.91 & 0.64 & 1.00 & & \\
Line3 & 0.41 & 0.40 & 0.43 & 0.35 & 0.33 & $\mathbf{1 . 0 0}$ & 0.73 & 0.91 & 1.00 & \\
Line4 & 0.36 & 0.42 & 0.38 & 0.30 & 0.29 & 0.91 & 0.80 & 0.82 & 0.91 & 1.00 \\
\hline
\end{tabular}

The data obtained from the SDS-PAGE analysis was used for the construction of dendrogram using UPGMA shown in Figure 2. The ten genotypes were grouped into two main clusters. Cluster $1^{\text {st }}$ contained two subclusters. First subcluster consisted of Rihane-3, Line2, Line3 and Line4 and Rihane-3 with Line3 had an identical electrophoretic pattern. Second sub cluster contained Line1 only. Some barley genotypes inevitably were clustered in the same or very close groups, due to the fact that they are genetically very similar and might share common ancestors. This may cause disadvantages for barley production in a breeding program. Cluster 2 contained two sub clusters. The first one consisted of Giza124 and Mari while the second contained Arar, Giza123 and Beecher. In addition, the cluster analysis revealed that Giza123 and Rihane- 3 are distinctly related to each other. The results partially agree with Alipour et al. (2002) studied the genetic variation in the electrophoretic patterns of proteins. Based on the relative mobility on the gel, 30 protein bands were obtained, of which only 5 bands varied among the accessions. Cluster analysis based on qualitative evaluation of the patterns grouped the accessions into 8 clusters and classified the different bands into 3 groups.

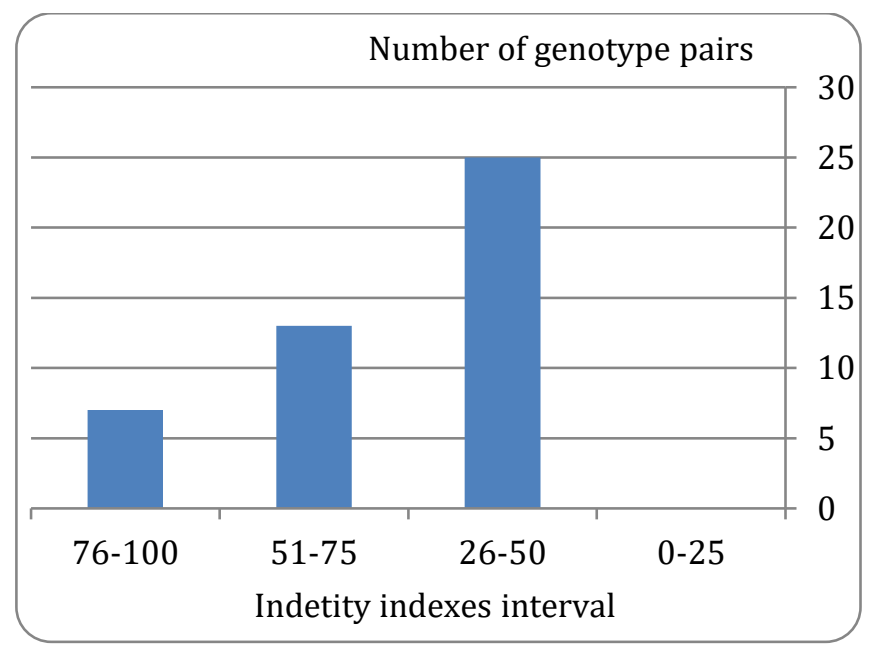

Figure 1. Distribution of identity indexes of protein pattern of ten barley genotypes. 


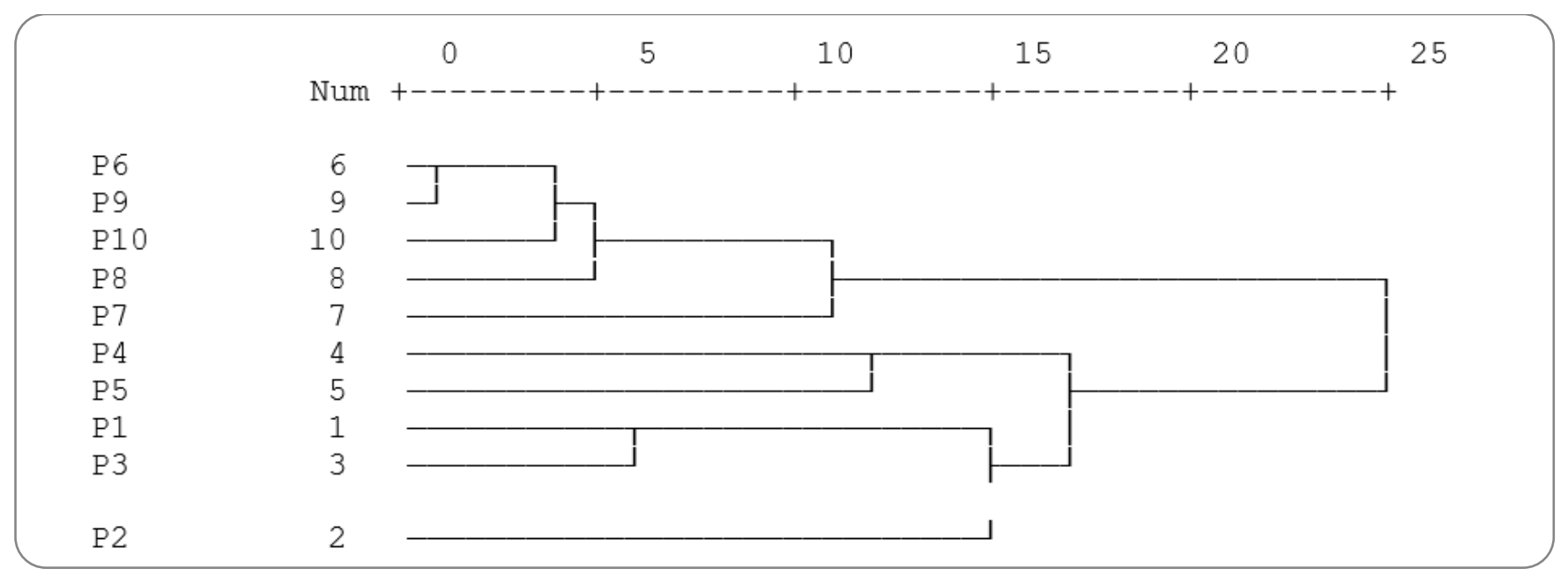

Figure 2. Dendrogram of 10 barley genotypes prepared based on SDS-PAGE data. Genotype codes: see Table 1.

\section{CONCLUSION}

Plant protein pattern is considered as the genotypic fingerprint. It is, therefore, used for several purposes such as plant variety protection, registration, certification, patents and as a breeding tool especially in breeding programs. Plant protein profiles could be a useful marker in the studies of genetic variation and classification of different cultivars, thereby improving the efficiency of breeding programs in cultivar development. The present study revealed variation in ten genotypes of barley about their protein profiles. According to the results of genetic diversity and relationships illustrated the ability to resolve genetic variation among ten genotypes may be more directly related to the number of polymorphism detected with SDS-Page protein electrophoresis.

Presently more and DNA-based markers are being used in studies related to plant genetic diversity and plant breeding. However, as cost well-trained scientists and technicians in modern techniques and funds are often limiting in developing countries, simpler and cheaper methods are needed in poor developing countries to progress in agricultural development. Therefore, SDSpage methods are reliable and economical techniques could be preferred, at least in the first screening of genetic variability. For the future works in this field, consequently, improving barley quality cannot be achieved without considering protein content and several gluten alleles. Considering all the different alleles and the numerous genetic combinations represent a considerable burden for geneticists. Hence, in the meantime, efforts to move on to modern techniques should continue to be able to study a larger number of crop genetic resources and enhance plant breeding capacity in the country.

\section{REFERENCES}

Abou-Ellail, M., M. E.-S. Hattem, A. M. Mohamed, I. A. Usama, A. G. Hassan and A. E. E. 2014. Appraisal of biochemical and genetic diversity of mango cultivars using molecular markers. African Journal of Biotechnology, 13: 2796-2806.

Ahmed, M. F., M. Iqbal, M. Shahid Masood, M. Ashiq Rabbani and M. Munir. 2010. Assessment of genetic diversity among Pakistani wheat (Triticum aestivum L.) advanced breeding lines using rapd and sds-page. Electronic Journal of Biotechnology, 13.

Al-Hadeithi, Z. S., A. K. A. Al-Kazaz and B. K. Al-Obaidi. 2012. Genetic diversity and relationships among Iraqi barley cultivars using RAPD-PCR technique. The Iraqi Journal of Agricultural Science, 43: 117124.

Ali, Z., A. S. Qureshi, W. Ali, H. Gulzar, M. Nisar and A. Ghafoor. 2007. Evaluation of genetic diversity present in pea (Pisum sativum L.) germplasm based on morphological traits, resistance to powdery mildew and molecular characteristics. Pakistan Journal of Botany, 39: 2739-2747.

Alipour, H., A. Rezai, S. A. M. Meibodi and M. Taheri. 2002. Evaluation of genetic variation in soybean lines using seed protein electrophoresis. JWSSIsfahan University of Technology, 5: 85-96.

Aman, R. A. 1995. A comparative assessment of molecular techniques employed in genetic diversity studies (and their suitability in resource- 
limited settings). in: W.G. Ayad, T. Hodgkin, A. Jaradat \& V.R. Rao (Eds.), IPGRI Workshop on Molecular Genetic Techniques for Plant Genetic Resources, Roma (Italia), 9-11 Oct 1995., p. 119127.

Baenziger, P. S., D. R. Shelton, M. J. Shipman and R. A. Graybosch. 2001. Breeding for End-Use Quality: Reflections on the Nebraska Experience. Wheat in a Global Environment. Springer Netherlands, p. 255-262.

Baloch, A. W., M. Ali, A. M. Baloch, B. N. Mangan and W. Song. 2014. Genetic diversity and structure analysis based on hordein protein polymorphism in barley landrace populations from Jordan. Pakistan Journal of Botany, 46: 1397-1402.

Bohn, M., H. F. Utz and A. E. Melchinger. 1999. Genetic Similarities among Winter Wheat Cultivars Determined on the Basis of RFLPs, AFLPs, and SSRs and Their Use for Predicting Progeny Variance. Crop Science, 39: 228.

Bradford, M. 1976. A Rapid and Sensitive Method for the Quantitation of Microgram Quantities of Protein Utilizing the Principle of Protein-Dye Binding. Analytical Biochemistry, 72: 248-254.

Chen, Z. W., R. J. Lu, L. Zou, Z. Z. Du, R. H. Gao, T. He and J. H. Huang. 2012. Genetic diversity analysis of barley landraces and cultivars in the Shanghai region of China. Genetics and Molecular Research, 11: 644-650.

Cooke, R. 1994. Variety Identification: Modcm Techniques and applications, In: A. Basra, (ed.), Seed quality: Basic mechanisms and agricultural implications. Haworth Press, New York, p. 279317.

Dakir, E. L. H., M.-L. Ruiz, P. García and M. Pérez de la Vega. 2002. Genetic variability evaluation in a Moroccan collection of barley, Hordeum vulgare L., by means of storage proteins and RAPDs. Genetic Resources and Crop Evolution, 49: 619631.

Echart-Almeida, C. and S. Cavalli-Molina. 2000. Hordein variation in Brazilian barley varieties (Hordeum vulgare L.) and wild barley (H. euclaston Steud. and H. stenostachys Godr.). Genetics and Molecular Biology, 23: 425-433.

Feng, Z.-Y., X.-J. Liu, Y.-Z. Zhang and H.-Q. Ling. 2006. Genetic Diversity Analysis of Tibetan Wild Barley Using SSR Markers. Acta Genetica Sinica, 33: $917-$
928.

Gardiner, S. E. and M. B. Forde. 1992. Identification of Cultivars of Grasses and Forage Legumes by SDSPAGE of Seed Proteins. Modern Methods of Plant Analysis. Springer Berlin Heidelberg, p. 43-61.

Ghaderi, M., P. Vojdani and A. Gerami. 2003. Genetic diversity in the Iranian landraces of barley and its relation to geographical and climatic variation. Journal of Agricultural Science and Technology, 9: 50-70.

Gianibelli, M. C., R. B. Gupta, D. Lafiandra, B. Margiotta and F. MacRitchie. 2001. Polymorphism of High MrGlutenin Subunits in Triticum tauschii: Characterisation by Chromatography and Electrophoretic Methods. Journal of Cereal Science, 33: 39-52.

Heisel, S. E., D. M. Peterson and B. L. Jones. 1986. Identification of United States barley cultivars by sodium dodecyl sulfate polyacrylamide gel electrophoresis of hordeins. Cereal Chemistry, 63: 500-505.

Javaid, A., A. Ghafoor and R. Anwar. 2004. Seed storage protein electrophoresis in groundnut for evaluating genetic diversity. Pakistan Journal of Botany, 36: 25-30.

Jisha, V., L. Dampanaboina, J. Vadassery, A. Mithöfer, S. Kappara and R. Ramanan. 2015. Overexpression of an AP2/ERF Type Transcription Factor OsEREBP1 Confers Biotic and Abiotic Stress Tolerance in Rice. PloS One, 10: 0127831.

Karp, A. 1995. Molecular techniques in the analysis of the extent and distribution of genetic diversity, In: W.G. Ayad, T. Hodgkin, A. Jaradat \& V.R. Rao, (eds.), Molecular Genetic Techniques for Plant Genetic Resources. International Plant Genetic Resource Institute, Rome, Italy, p. 11-22.

Karuppanapandian, T., T. Karuppudurai, P. B. Sinha, A. M. K. Haniya and K. Manoharan. 2006. Phylogenetic diversity and relationships among Cowpea (Vigna unguiculata L. Walp.) landraces using Random Amplified Polymor-Phic DNA markers. Plant Physiology, 32: 141-152.

Kut'ka-Hlozákovás, T., E. Gregova, M. Vivodik and Z. Gálová. 2016. Genetic diversity of European cultivars of common wheat (Triticum aestivum L.) based on RAPD and protein markers. Journal of Central European Agriculture, 17: 957-969.

Laemmli, U. K. 1970. Cleavage of structural proteins 
during the assembly of the head of bacteriophage T4. Nature, 227: 680-685.

Lawrence, G. J. and K. W. Shepherd. 1980. Variation in Glutenin Protein Subunits of Wheat. Australian Journal of Biological Sciences, 33: 221.

Maris, A. 1992. Characterization isoenzyme of Brazilian cultivars of Hordeum vulgare. (Unpublished) Bachelor's thesis, University of Federal Rio Grand do Sul, Porto Alegre. RS.

Masoudi, B., M. R. Bihamta, H. R. Babaei and S. A. Peyghambari. 2008. Evaluation of genetic diversity for agronomic, morphological and phenological traits in soybean. Journal of Plant and Seed, 24: 413-427.

Masoumi, S. M., D. Kahrizi, H. Rostami-Ahmadvandi, J. Soorni, S. Kiani, A. Mostafaie and K. Yari. 2012. Genetic diversity study of some medicinal plant accessions belong to Apiaceae family based on seed storage proteins patterns. Molecular Biology Reports, 39: 10361-10365.

Mer, R. K., P. K. Prajith, D. H. Pandya and A. N. Pandey. 2000. Effect of Salts on Germination of Seeds and Growth of Young Plants of Hordeum vulgare, Triticum aestivum, Cicer arietinum and Brassica juncea. Journal of Agronomy and Crop Science, 185: 209-217.

Mzid, R., F. Chibani, R. B. Ayed, M. Hanana, J. Breidi, R. Kabalan, S. El-Hajj, H. Machlab, A. Rebai and L. Chalak. 2016. Genetic diversity in barley landraces (Hordeum vulgare L. subsp. vulgare) originated from Crescent Fertile region as detected by seed storage proteins. Journal of Genetics, 95: 733-739.

Pe'rez de, M. 1993. Biochemical characterization of populations, In: H. M.D., B. N.O. \& R. I., (eds.), Plant Breeding - Principles and Prospects. Chapman \& Hall, London, UK, p. 184-200.

Pournosrat, R., S. Kaya, S. Shaaf, B. Kilian and H. Ozkan. 2018. Geographical and environmental determinants of the genetic structure of wild barley in southeastern Anatolia. PloS one, 13: 0192386.

Radwan, S. A., A. S. El-Koly and R. H. Sammour. 2013. Genetic variation among accessions of Lathyrus inconspicuous (L.) as revealed by SDS Polyacrylamide Gel Electrophoresis / Analiza genetske variabilnosti akcesij grahorja (Lathyrus inconspicuous (L.) s SDS poliakrilamidno gelsko elektroforezo. Acta agriculturae Slovenica, 101:
21-30.

Redden, B., N. Maxted, B. Furman and C. Coyne. 2007. Lens biodiversity, In: S.S. Yadav, D.L. McNeil \& P.C. Stevenson, (eds.), Lentil an ancient crop for modern times. Springer, Netherlands, p. 10-22.

Rohlf, F. J. 1987. NTSYS-pc: Microcomputer Programs for Numerical Taxonomy and Multivariate Analysis. The American Statistician, 41: 330.

Sadia, M., S. A. Malik, M. A. Rabbani and S. R. Pearce. 2009. Electrophoretic characterization and the relationship between some Brassica species. Electronic Journal of Biology, 5: 1-4.

Saisho, D. and K. Takeda. 2011. Barley: Emergence as a New Research Material of Crop Science. Plant and Cell Physiology, 52: 724-727.

Sharma, D. B. and K. Krishna. 2017. Genetic Diversity in Cowpea (Vigna unguiculata (L.) Walp.) Accessions using Protein Profiling. International Journal of Pure \& Applied Bioscience, 5: 491-496.

Shekhghasemi, A. R., R. Shahryari and V. Mollasadeghi. 2013. Analysis of genetic diversity in barley genotypes using storage proteins. International Journal of Farming and Allied Sciences, 2: 448453.

Shewry, P. R. 1995. Plant Storage Proteins. Biological Reviews, 70: 375-426.

Shuaib, M., I. Khan, Z. Ali, W. Ali, T. Ahmad and A. Zeb. 2007. Evaluation of Different Wheat Varieties by SDS-PAGE Electrophoresis. Pakistan Journal of Biological Sciences, 10: 1667-1672.

Tripathy, S. K., P. Mohanty, M. Jena, G. B. Dash, K. Pradhan, P. K. Nayak, S. Dash, D. Lenka, D. Mishra, P. M. Mohapatra, D. Swain and N. Senapati. 2016. Revealing contrasting genetic variation and study of genetic diversity in urdbean (Vigna mungo (L.) Hepper) using SDS-PAGE of seed storage proteins. Research in Biotechnology, 7.

Vargas, E., G. Macaya, J. Baudoin and O. Rocha. 2001. Case studies on breeding systems and its consequences for germplasm conservation: 3 . Electrophoretic mobility of phaseolins in wild populations of Lima beans (Phaseolus lunatus L.) in the Central Valley of Costa Rica. Genetic Resources and Crop Evolution, 48: 109-120.

Zhang, D. and Y. Ding. 2007. Genetic diversity of wild close relatives of barley in Tibet of China revealed by AFLP. Hereditas, 29: 725-730. 